\title{
PENGUASAAN KOSAKATA TERHADAP KEMAMPUAN BERBICARA BAHASA INDONESIA SISWA KELAS VI SEKOLAH MADRASAH IBTIDAIYAH PANGERAN HIDAYATULLAH \\ (Vocabulary Mastery of the Ability to Speak Indonesia Students of Class VI School of Madrasah Ibtidaiyah Pangeran Hidayatullah)
}

\author{
Hestiyana \\ Balai Bahasa Kalimantan Selatan \\ Jalan Jend. A.Yani Km 32, Banjarbaru, Kalimantan Selatan \\ Pos-el: hestiyana21@gmail.com
}

(Diterima: 20 April 2019; Direvisi: 7 Mei 2019; Disetujui: 28 Mei 2019)

\begin{abstract}
This study aims to describe the mastery of Indonesian vocabulary and the ability to speak Indonesian students of class VI school of Madrasah Ibtidaiyah Pangeran Hidayatullah. This research uses quantitative descriptive research. The object of this research was students of class VI school of Madrasah Ibtidaiyah Pangeran Hidayatullah with a saturated sampling technique. Instruments used in data collection, namely: test sheets, observation guidelines, and documentation. Data analysis was performed using descriptive statistical analysis. Based on the results of the analysis, it can be seen that the mastery of Indonesian vocabulary and the ability to speak Indonesian in students of class VI school of Madrasah Ibtidaiyah Pangeran Hidayatullah are in the moderate category. Mastery of Indonesian vocabulary has an average value of 24.40 which is in the interval 23-24 so it can be stated that the mastery of Indonesian vocabulary of students is in the medium category. Then, the ability to speak Indonesian in students of class VI school of Madrasah Ibtidaiyah Pangeran Hidayatullah was in the moderate category with an average value of 10.08 in intervals of $10-11$ so that students' speaking ability was in the medium category.
\end{abstract}

Keywords: mastery of vocabulary, speaking ability, Indonesian

Abstrak

Penelitian ini bertujuan mendeskripsikan penguasaan kosakata bahasa Indonesia dan kemampuan berbicara bahasa Indonesia siswa kelas VI Sekolah Madrasah Ibtidaiyah Pangeran Hidayatullah. Penelitian ini menggunakan jenis penelitian deskriptif kuantitatif. Objek penelitian ini adalah siswa kelas VI Sekolah Madrasah Ibtidaiyah Pangeran Hidayatullah dengan teknik pengambilan sampel jenuh. Instrumen yang digunakan dalam pengumpulan data, yaitu: lembar tes, pedoman observasi, dan dokumentasi. Analisis data dilakukan dengan menggunakan analisis statistik deskriptif. Berdasarkan hasil analisis dapat diketahui bahwa penguasaan kosakata bahasa Indonesia dan kemampuan berbicara bahasa Indonesia siswa kelas VI Sekolah Madrasah Ibtidaiyah Pangeran Hidayatullah berada pada kategori sedang. Penguasaan kosakata bahasa Indonesia memiliki nilai rata-rata sebesar 24,40 yang berada pada interval 23-24 sehingga dapat dinyatakan bahwa penguasaan kosakata bahasa Indonesia siswa berada pada kategori sedang. Kemudian, kemampuan berbicara bahasa Indonesia siswa kelas VI Sekolah Madrasah Ibtidaiyah Pangeran Hidayatullah berada pada kategori sedang dengan nilai rata-rata sebesar 10,08 yang berada pada interval 10-11 sehingga dapat dinyatakan bahwa kemampuan berbicara siswa berada pada kategori sedang.

Kata-kata kunci: penguasaan kosakata, kemampuan berbicara, Bahasa Indonesia

\section{PENDAHULUAN}

Pembelajaran bahasa di sekolah mempunyai peranan yang sangat penting bagi siswa dalam mengembangkan kemampuan bahasanya. Keterampilan berbahasa memiliki empat komponen, yaitu: (1) keterampilan menyimak (listening skills), (2) keterampilan berbicara (speaking skills),
(3) keterampilan membaca (reading skills), dan (4) keterampilan menulis (writing skills) (Nida dan Haris dalam Tarigan, 2015: 1). Keempat keterampilan berbahasa tersebut saling berkaitan satu sama lain dan akan memudahkan siswa memahami materi pelajaran yang disampaikan guru. 
Keterampilan berbicara sangat diperlukan sebagai alat untuk menyatakan gagasan dan memberikan pesan atau informasi kepada orang lain. Keterampilan berbahasa seseorang sangat dipengaruhi kuantitas dan kualitas kosakata yang dikuasainya. Semakin kaya kosakata yang dimiliki seseorang, semakin besar pula kemungkinan seseorang tersebut terampil berbicara. Hal ini seperti yang dikemukakan Labov dan Fishman (dalam Mulyati, 2017: 100) bahwa semakin tinggi usia seseorang maka akan semakin banyak kata yang dikuasainya.

Perbendaharaan kosakata yang dimiliki siswa, tentunya akan berpengaruh kepada kemampuan berbicaranya. Hal ini akan meningkatkan kualitas diri siswa tersebut karena berdampak pula pada kualitas pendidikannya. Sakila (2017: 199) menyatakan bahwa peningkatan mutu pendidikan diarahkan untuk meningkatkan kualitas manusia Indonesia seutuhnya melalui olah hati, olah pikir, olah rasa, dan olahraga agar memiliki daya saing dalam menghadapi tantangan global.

Kemampuan berbicara merupakan kemampuan dalam mengungkapkan pikiran, gagasan, dan menyampaikan informasi kepada orang lain. Selain itu, dalam kemampuan berbicara juga diperlukan pengetahuan mengenai teori dan terapan berbicara. Dalam hal ini, guru mempunyai peranan penting untuk meningkatkan kemampuan berbicara siswa di sekolah. Tarigan (2015: 32) menyatakan bahwa kemampuan berbicara seseorang turut menentukan kesuksesan kariernya. Berbicara merupakan suatu daya pemersatu yang ampuh yang cenderung mempersatukan kelompok-kelompok sosial.

Proses pembelajaran yang berlangsung di kelas merupakan hal yang mendasar dalam dunia pendidikan. Hal ini seperti yang dikemukakan Long (dalam Hestiyana, 2017: 160) bahwa apa yang berlangsung di dalam kelas merupakan salah satu unsur yang sangat penting dalam menentukan pembelajar memperoleh bahasa. Baradja (dalam Budiyono, 2014: 175) mengemukakan bahwa pembelajaran, pada hakikatnya terjadi dalam interaksi sosial. Interaksi tersebut terjadi dalam kelas yang ditandai oleh adanya kontak timbal-balik antara pengajar dengan pembelajar dan antara pembelajar dengan pembelajar.

Tarigan (2015:2) menambahkan bahwa kenaikan kelas para siswa di sekolah ditentukan oleh kualitas keterampilan berbahasa mereka. Dengan kata lain, pembelajaran di kelas mempunyai peran penting dalam meningkatkan kuantitas dan kualitas kosakata serta kemampuan berbicara siswa.

Dengan demikian, dalam proses pembelajaran guru juga harus meningkatkan kualitas keterampilan berbahasa siswa karena pada kenyataannya penguasaan kosakata siswa masih rendah. Hal ini mengakibatkan siswa belum dapat berkomunikasi dengan baik ketika menyampaikan gagasan, pendapat, atau keinginannya. Rendahnya penguasaan kosakata bahasa Indonesia tidak hanya berpengaruh pada keterampilan berbicara saja, tetapi juga berdampak pada ketiga keterampilan bahasa yang lainnya, seperti menyimak, membaca, dan menulis.

Melalui pembelajaran bahasa yang berkaitan dengan penguasaan kosakata, pemberian stimulasi, dan pengembangan aspek-aspek bahasa diharapkan siswa memiliki keterampilan berbicara yang baik sehingga dengan mudah siswa dapat mengungkapkan pendapat, ide, dan gagasannya kepada orang lain. Hal inilah yang menarik untuk dikaji lebih dalam. Oleh karena itu, penguasaan kosakata bahasa Indonesia dalam penelitian ini difokuskan pada keterampilan berbicara.

Penelitian terdahulu yang relevan dengan penelitian ini yang dapat dijadikan sebagai tinjauan pustaka, di antaranya yang dilakukan Widyastuti (2016) dengan judul "Pengaruh Minat Membaca dan Penguasaan Kosakata terhadap Keterampilan Berbicara Pidato." Dari hasil penelitian tersebut ditemukan bahwa peserta didik kelas VIII 
SMP Swasta di Kota Depok, yaitu: (1) terdapat pengaruh yang signifikan minat membaca dan penguasaan kosakata secara bersama-sama terhadap keterampilan berbicara pidato, (2) terdapat pengaruh yang positif dan signifikan minat membaca terhadap keterampilan berbicara pidato, dan (3) terdapat pengaruh yang positif dan signifikan terhadap keterampilan berbicara pidato.

Rusda (2017) melakukan penelitian yang berjudul "Pengaruh Penguasaan Kosakata terhadap Kemampuan Berbicara Bahasa Indonesia Peserta Didik di SDN 2 Pulau Sarappo Lompo Kecamatan Liukang Tupabbiring Kabupaten Pangkep." Hasil penelitiannya menunjukkan bahwa penguasaan kosakata bahasa Indonesia peserta didik SDN 2 Pulau Sarappo Lompo berada pada kategori sedang dengan nilai rata-rata 23,3; kemampuan berbicara peserta didik berada pada kategori rendah dengan nilai rata-rata 8,660 ; dan terdapat pengaruh yang signifikan antara keduanya. Ini terlihat dari tabel korelasi, yakni ada pengaruh penguasaan kosakata terhadap kemampuan berbicara bahasa Indonesia peserta didik sebesar 0,167 dengan tingkat signifikansi 1,000, dengan demikian $\mathrm{H}_{0}$ ditolak dan $\mathrm{H}_{1}$ diterima.

Berbeda dengan penelitian sebelumnya, masalah dalam penelitian ini, yaitu: (1) bagaimana penguasaan kosakata bahasa Indonesia siswa kelas VI Sekolah Madrasah Ibtidaiyah Pangeran Hidayatullah? dan (2) bagaimana kemampuan berbicara bahasa Indonesia siswa kelas VI Sekolah Madrasah Ibtidaiyah Pangeran Hidayatullah?

Tujuan penelitian ini, yaitu mendeskripsikan penguasaan kosakata bahasa Indonesia siswa kelas VI Sekolah Madrasah Ibtidaiyah Pangeran Hidayatullah dan mendeskripsikan kemampuan berbicara bahasa Indonesia siswa kelas VI Sekolah Madrasah Ibtidaiyah Pangeran Hidayatullah.

Hasil penelitian ini diharapkan dapat menjadi acuan dan bahan pengembangan pengajaran kosakata terhadap kemampuan berbicara bahasa Indonesia. Bagi kalangan pendidikan, penelitian ini juga dapat menjadi referensi yang menyangkut faktor-faktor dan upaya meningkatkan keterampilan berbicara siswa. Selain itu, penelitian ini juga dapat menjadi referensi bagi peneliti yang akan melakukan kajian sejenis.

\section{LANDASAN TEORI}

Perbendaharaan kata atau kosakata sebagai satuan bahasa digunakan manusia untuk keperluan komunikasi. Kosakata merupakan sarana yang sangat penting dalam menunjang kelancaran manusia berkomunikasi karena pada umumnya kelancaran komunikasi seseorang bergantung pada kosakatanya. Seberapa banyak kosakata yang dimiliki seseorang juga menunjukkan baik kualitasnya berbicaranya. Dalam hal ini, cara bertutur seseorang merupakan alat ukur bagi kualitas dan kuantitas berbahasa mereka. Nurhadi (1995: 330) menyatakan bahwa penutur yang baik adalah mereka yang memiliki kekayaan kata yang lebih dari cukup sehingga mereka mampu berkomunikasi dengan penutur bahasa lain.

Schmidt (2010: 629) menyatakan bahwa kosakata adalah aturan kata yang meliputi satu kata, gabungan kata, dan sebuah ungkapan. Kemudian, Subana \& Sunarti (2012: 252) mengemukakan bahwa kosakata merupakan perbendaharaan kata atau kekayaan kata yang dipakai. Pendapat yang sama disampaikan Soenardi (2009: 126) yang menyatakan bahwa kosakata merupakan perbendaharaan kata. Soedjito (dalam Tarigan, 2012: 12) mengemukakan bahwa kosakata merupakan: (1) semua kata yang terdapat dalam suatu bahasa; (2) kekayaan kata yang dimiliki oleh seseorang berbicara; (3) kata yang dipakai dalam suatu bidang ilmu pengetahuan; dan (4) daftar kata yang disusun seperti kamus disertai penjelasan secara singkat dan praktis.

Dengan demikian, kosakata merupakan perbendaharaan kata atau kekayaan kata yang dimiliki seseorang yang meliputi satu kata, gabungan kata, dan sebuah ungkapan yang berfungsi untuk 
membentuk kalimat, mengungkapkan pikiran, gagasan, maupun perasaan sehingga mampu berkomunikasi dengan baik.

Kosakata dasar adalah kata-kata yang tidak mudah berubah atau sedikit sekali kemungkinannya dipungut dari bahasa lain. Kosakata dasar terdiri atas: (1) istilah kekerabatan, misalnya: ayah, ibu, anak, adik, kakak, nenek, kakek, paman, bibi, menantu, dan mertua; (2) nama-nama bagian tubuh, misalnya: kepala, rambut, mata, telinga, hidung, mulut, bibir, dan sebagainya; (3) kata ganti, misalnya: saya, kamu, dia, kami, kita, mereka, ini, itu; (4) kata bilangan pokok, misalnya: satu, dua, tiga, empat, lima, dan sebagainya; (5) kata kerja pokok, misalnya: makan, minum, tidur, bangun, berbicara, melihat, dan sebagainya; (6) kata keadaan pokok, misalnya: suka, duka, senang, susah, lapar, haus, sakit, sehat, dan sebagainya; dan (7) benda-benda universal, misalnya: tanah, air, api, udara, langit, bulan, bintang, matahari, binatang, tumbuhtumbuhan (Tarigan, 2012: 13).

Hurlock (dalam Pramesti, 2015: 84) mengemukakan kosakata yang harus dikuasai oleh anak-anak usia 6-13 tahun atau siswa SD ada dua jenis, yakni kosakata umum dan kosakata khusus. Kosakata umum, mencakup kata-kata umum yang digunakan manusia untuk berkomunikasi, yakni kata kerja, kata benda, kata sifat, kata keterangan, kata perangkai atau kata ganti orang. Berbeda dengan kosakata umum, kosakata khusus merupakan kata-kata khusus yang meliputi hal-hal tertentu, seperti kosakata waktu, warna, uang, kosakata rahasia, kosakata populer, dan kosakata makian.

Fungsi kosakata dijelaskan Tarigan (2015: 10), antara lain: (1) fungsi instrumental (the instrumental function), yakni melayani pengelolaan lingkungan, menyebabkan peristiwa-peristiwa tertentu terjadi; (2) fungsi regulasi (theregulatory function) bahasa, yakni untuk mengawasi serta mengendalikan peristiwa-peristiwa; (3) fungsi representasional (the representational function), yakni penggunaan bahasa untuk membuat pernyataan-pernyataan, menyampaikan kata-kata dan pengetahuan, menjelaskan atau melaporkan; (4) fungsi interaksional (the interactional function), yakni komunikasi untuk menjamin serta memantapkan ketahanan dan kelangsungan komunikasi sosial; (5) fungsi personal the personal function), yakni melibatkan kepada seseorang pembicara untuk mengekspresikan perasaan, emosi, pribadi, serta reaksireaksinya yang mendalam tentang kepribadian seseorang yang ditandai dengan penggunaan fungsi personal bahasanya dalam komunikasi; (6) fungsi heuristik (the heuristic function), yakni melibatkan penggunaan bahasa untuk memperoleh ilmu pengetahuan dan mempelajari seluk beluk lingkungan yang disampaikan dalam bentuk pernyataan-pernyataan yang menuntut jawaban; (7) fungsi imajinatif (the imaginative function), yakni melayani penciptaan sistem-sistem ataupun gagasangagasan yang bersifat imajinatif.

Kosakata mempunyai peran yang sangat penting dalam berkomunikasi. Dalam proses pembelajaran yang berlangsung di kelas, kosakata siswa dipengaruhi oleh faktor usia. Hal ini seperti yang diungkapkan Roberts (2014: 23-24) bahwa penguasaan kosakata siswa akan berjenjang sesuai dengan taraf perkembangan usianya.

Kosakata atau perbendaharaan kata merupakan pusat seluruh pengajaran bahasa. Hal itu tentu bukan sesuatu yang berlebihan mengingat begitu pentingnya penguasaan perbendaharaan kata dalam berkomunikasi (Soejono dalam Subyantoro, 2012, hlm. 712).

Arah pembelajaran kosakata adalah untuk mengembangkan minat para siswa pada kata-kata. Usaha memperkaya kosakata perlu dilakukan secara terus-menerus mencakup segi atau bidang yang disesuaikan dengan tingkat usia, perkembangan, dan pengalaman siswa (Depdikbud dalam Subyantoro, 2012: 710).

Mengingat pentingnya kosakata sebagai salah satu materi pelajaran bahasa Indonesia di sekolah dan menjadi dasar 
siswa menguasai materi pelajaran yang lain sehingga penguasaan kosakata siswa perlu ditingkatkan. Dengan penguasaan kosakata yang baik akan mempengaruhi cara berpikir dan daya kreativitas siswa dalam menerima pelajaran. Selain itu, siswa yang memiliki kemampuan kosakata yang tinggi akan memilih kata yang tepat sebagai wakil dalam menyampaikan pikiran, perasaan, ataupun idenya.

Dalam pembelajaran di sekolah, pencapaian keterampilan berbicara diperlukan sebagai alat untuk menyampaikan pikiran, ide, gagasan, ataupun perasaan. Hornby (2010: 721) menyatakan pencapaian itu sendiri adalah keterampilan yang bagus atau sebuah pengetahuan. Subana dan Sunarti (2012: 124) mengemukakan bahwa tujuan utama pendidikan atau pembelajaran bahasa Indonesia adalah melatih siswa berbahasa Indonesia secara terampil. Solchan, dkk (2009: 131) menambahkan bahwa belajar bahasa Indonesia untuk siswa SD pada dasarnya bertujuan untuk mengasuh dan membekali mereka dengan kemampuan berkomunikasi atau kemampuan menerapkan bahasa Indonesia dengan tepat untuk berbagai tujuan dan dalam konteks yang berbeda.

Mulgrave (dalam Widyastuti, 2016: 30) menyatakan bahwa berbicara adalah kemampuan mengucapkan bunyi-bunyi bahasa atau kata-kata untuk mengekspresikan. Pendapat yang sama dikemukakan Tarigan (dalam Wendra, 2009: 3) bahwa berbicara adalah kemampuan mengucapkan bunyi-bunyi artikulasi atau kata-kata untuk mengekspresikan, menyatakan, serta menyampaikan pikiran, gagasan, dan perasaan seseorang.

Kemudian, Marrie dan Kenneth (dalam Widyastuti, 2016: 30) mengatakan bahwa pada hakikatnya berbicara adalah suatu proses pemindahan pesan dari suatu sumber kepada sumber yang lain. Hal serupa dikemukakan Haryadi dan Zamzani (dalam Mabruri dan Ferry, 2017: 113) bahwa secara umum berbicara dapat diartikan sebagai suatu penyampaian maksud (ide, pikiran, isi hati) seseorang kepada orang lain dengan menggunakan bahasa lisan sehingga maksud tersebut dapat dipahami orang lain.

Menurut Haris (dalam Tarigan, 2015: 3), terdapat 4 komponen keterampilan berbicara yang harus diperhatikan, yaitu: (1) fonologi (bunyi), (2) struktur kalimat, (3) kosakata, dan (4) kelancaran (ketepatan). Hurlock (dalam Ayuandia, dkk, 2017: 35) menjelaskan ada dua tipe karakteristik berbicara anak, yaitu: (1) berbicara yang berpusat pada orang lain (sosialisasi) adalah berbicara yang disesuaikan dengan harapan orang lain yang diajak berbicara dan (2) berbicara yang berpusat pada diri sendiri (egosentrik) adalah anak berbicara bagi kesenangan diri mereka sendiri. Tujuan umum dalam pengembangan keterampilan berbicara anak, antara lain: (1) memiliki perbendaharaan kata yang cukup yang diperlukan untuk berkomunikasi sehari-hari, (2) mau mendengarkan dan memahami katakata serta kalimat, (3) mampu mengungkapkan pendapat dan sikap dengan lafal yang tepat, (4) berminat menggunakan bahasa yang baik, dan (5) berminat untuk menghubungkan antara bahasa lisan dan bahasa tulisan (Hartono dalam Ayuandia, dkk, 2017: 35-36). Berbicara merupakan kemampuan mengekspresikan, menyatakan, serta menyampaikan pikiran, gagasan, dan perasaan seseorang melalui pemindahan pesan dari suatu sumber kepada sumber yang lain. Keterampilan berbicara dalam pembelajaran di sekolah, terutama pada siswa SD bisa dimulai dengan meningkatan perbendaharaan kosakata, memperbaiki struktur kalimat, dan melatih keberanian siswa dalam menyampaikan pendapatnya.

\section{METODE}

Penelitian ini menggunakan metode deskriptif dengan pendekatan kuantitatif karena data-data penelitian berupa angkaangka. Nawawi \& Martini (2012: 67) mengatakan metode deskriptif adalah prosedur pemecahan masalah yang diselidiki dengan menggambarkan atau melukiskan 
keadaan subjek atau objek penelitian (seseorang, lembaga, masyarakat, dan lainlain) pada saat sekarang berdasarkan faktafakta yang tampak atau sebagaimana adanya. Purwanto (2016: 7) mengatakan penelitian kuantitatif merupakan penelitian yang menghasilkan data numerikal dan memakai prosedur statistik untuk menggeneralisasikan temuan penelitian pada sampel ke populasi.

Populasi adalah wilayah generalisasi yang terdiri atas objek/subjek yang mempunyai kualitas dan karakteristik tertentu yang ditetapkan oleh peneliti untuk dipelajari dan kemudian ditarik kesimpulannya (Sugiyono, 2016: 119). Purwanto (2016: 100) menyatakan bahwa populasi adalah sebuah kelompok yang hasil-hasil sebuah penelitian yang dilakukan akan digeneralisasikan. Tegasnya, sebuah populasi selalu terdiri atas sekelompok individu (objek) yang memiliki sebuah (sejumlah) karakteristik tertentu yang sama. Dalam penelitian ini yang menjadi populasi adalah seluruh siswa kelas VI siswa Sekolah Madrasah Ibtidaiyah Pangeran Hidayatullah yang berjumlah 25 siswa.

Sugiyono (2016: 120) menyatakan bahwa sampel adalah bagian dari jumlah dan karakteristik yang dimiliki oleh populasi tersebut. Pendapat yang sama dikemukakan Purwanto (2016: 100) bahwa di dalam konteks penelitian, istilah sampel menunjuk pada sebuah kelompok yang peneliti dapat memperoleh informasi yang akan digeneralisasikan kepada kelompok yang lebih besar.

Penelitian ini mengacu pada sampel yang dikemukakan Riduwan (2019: 21) yang menyatakan bahwa jika anggota populasi kurang dari 100 orang, maka seluruh anggota populasi dijadikan sampel atau sampel non probability sampling jenis sampel jenuh. Adapun sampel dalam penelitian ini berjumlah 25 siswa sehingga jenis teknik pengambilan sampel jenuh. Teknik yang digunakan dalam pengumpulan data, yakni tes, observasi, dan dokumentasi. Tes pada penelitian ini digunakan untuk memperoleh data penguasaan kosakata bahasa Indonesia siswa kelas VI Sekolah Madrasah Ibtidaiyah Pangeran Hidayatullah. Kemudian, observasi adalah suatu proses pengamatan dan pencatatan secara sistematis, logis, objektif, dan rasional mengenai berbagai fenomena (Arifin, 2014: 153). Dalam penelitian ini, observasi digunakan untuk memperoleh data kemampuan berbicara siswa kelas VI Sekolah Madrasah Ibtidaiyah Pangeran Hidayatullah. Selanjutnya, dokumentasi digunakan untuk mendapatkan daftar nama siswa kelas VI Sekolah Madrasah Ibtidaiyah Pangeran Hidayatullah.

Penelitian ini menggunakan instrumen sebagai alat untuk memperoleh data. Sugiyono (2016: 148) menyatakan bahwa instrumen penelitian adalah suatu alat yang digunakan untuk mengukur fenomena alam maupun sosial yang diamati. Secara spesifik semua fenomena ini disebut variabel penelitian. Dalam hal ini instrumen yang digunakan dalam pengumpulan data, antara lain: (1) lembar soal cerita, (2) pedoman observasi, dan (3) dokumentasi. Dalam penelitian ini, lembar soal cerita digunakan untuk mengetahui penguasan kosakata bahasa Indonesia, yakni dengan memberikan tes lisan berupa cerita rakyat dari Kalimantan Selatan. Dipilihnya cerita rakyat karena untuk mengetahui sejauh mana pengetahuan siswa mengenai cerita rakyat dari Kalimantan Selatan serta untuk mengetahui daya literasi siswa. Setelah itu siswa menyebutkan masing-masing 5 kata kerja, kata benda, dan kata sifat. Kemudian, pedoman observasi digunakan untuk mengetahui kemampuan berbicara dengan cara siswa membaca cerita rakyat dari Kalimantan Selatan. Setelah selesai membaca cerita tersebut, siswa menceritakan kembali isi cerita dengan aspek penilaian antara lain: (1) pengucapan, (2) artikulasi, (3) intonasi, (4) pemilihan kata, (5) mimik, dan (6) pemakaian bahasa yang baku. Selanjutnya, dokumentasi dilakukan untuk mengetahui daftar nama-nama siswa kelas VI. 
Teknik analisis data digunakan untuk menganalisis data hasil penguasaan kosakata dan kemampuan berbicara siswa kelas VI Sekolah Madrasah Ibtidaiyah Pangeran Hidayatullah dengan cara menghitung skor rata-rata, skor tertinggi, skor terendah dan menentukan kategorisasi dengan acuan rumus seperti yang dikemukakan Azwar (2013: 149), yaitu:

Interval $=\underline{\text { skor tertinggi-skor terendah }}$ Jumlah kategori

\section{PEMBAHASAN}

Data yang sudah diperoleh akan dianalisis menggunakan analisis statistik deskriptif. Berikut akan dijelaskan hasil analisisnya.

\section{Penguasaan Kosakata Bahasa Indonesia Siswa Kelas VI Sekolah Madrasah Ibtidaiyah Pangeran Hidayatullah}

Berdasarkan penelitian yang dilakukan pada siswa kelas VI Sekolah Madrasah Ibtidaiyah Pangeran Hidayatullah, maka diperoleh data sebagai berikut:

Tabel 1.1

Hasil Penelitian Mengenai Penguasaan Kosakata Bahasa Indonesia

\begin{tabular}{|c|c|c|}
\hline No. & Nama Siswa & Nilai \\
\hline 1 & A. Kholifa Husain & 28 \\
\hline 2 & Ahmad Khulaify & 28 \\
\hline 3 & A. Mursyidi & 26 \\
\hline 4 & A. Ridha & 24 \\
\hline 5 & Fadhila & 26 \\
\hline 6 & Nayla Rahma Izzati & 26 \\
\hline 7 & Nayna Salsabilla D.S & 26 \\
\hline 8 & Nur Ahro Zihah & 20 \\
\hline 9 & Nur Askiya & 24 \\
\hline 10 & Nur Kholishoh & 24 \\
\hline 11 & Nur Syifa & 22 \\
\hline 12 & Nurul Azkia & 22 \\
\hline
\end{tabular}

\begin{tabular}{|c|c|c|}
\hline 13 & Magfiroh Husna Rifa'i & 24 \\
\hline 14 & Mariatul Khibtiah & 22 \\
\hline 15 & M. Ahsan Rama Dhoni & 26 \\
\hline 16 & M. Fauzi & 26 \\
\hline 17 & M. Ismail & 22 \\
\hline 18 & M. Naufal & 24 \\
\hline 19 & M. Rifki & 20 \\
\hline 20 & M. Subhan & 24 \\
\hline 21 & Mustofa & 28 \\
\hline 22 & Robiatul Adawiah & 22 \\
\hline 23 & Siti Munawarah & 24 \\
\hline 24 & Siti Nawilah & 28 \\
\hline 25 & Soraya Zaida & 24 \\
\hline & Jumlah & 610 \\
\hline
\end{tabular}

Untuk mengetahui penguasaan kosakata bahasa Indonesia siswa kelas VI Sekolah Madrasah Ibtidaiyah Pangeran Hidayatullah, maka data tabel 1.1 akan dideskripsikan per indikator sesuai dengan hasil tes yang dinilai. Berdasarkan penilaian yang telah dibuat dan dari hasil perhitungan statistik diperoleh data sebagai berikut:

Tabel 1.2 Pemilihan Kata Kerja

\begin{tabular}{|c|c|c|}
\hline $\begin{array}{c}\text { Jumlah Kata } \\
\text { Kerja }\end{array}$ & Frekuensi & Persentase \\
\hline 5 & 9 & 36,00 \\
\hline 4 & 8 & 32,00 \\
\hline 3 & 6 & 24,00 \\
\hline 2 & 2 & 8,00 \\
\hline 1 & 0 & 0,00 \\
\hline Jumlah & 25 & 100 \\
\hline
\end{tabular}

Data pada tabel 1.2 menunjukkan bahwa dari jumlah 25 siswa maka terdapat 9 siswa yang bisa menyebutkan 5 kosakata kerja dengan persentase $36 \%$; terdapat 8 siswa yang bisa menyebutkan 4 kosakata kerja dengan persentase $32 \%$; terdapat 6 
siswa yang bisa menyebutkan 3 kosakata kerja dengan persentase $24 \%$; dan terdapat 2 siswa yang hanya menyebutkan 2 kosakata kerja dengan persentase $8 \%$.

\section{Tabel 1.3 Pemilihan Kata Benda}

\begin{tabular}{|c|c|c|}
\hline $\begin{array}{c}\text { Jumlah Kata } \\
\text { Benda }\end{array}$ & Frekuensi & Persentase \\
\hline 5 & 11 & 44,00 \\
\hline 4 & 10 & 40,00 \\
\hline 3 & 3 & 12,00 \\
\hline 2 & 1 & 4,00 \\
\hline 1 & 0 & 0,00 \\
\hline Jumlah & 25 & 100 \\
\hline
\end{tabular}

Data pada tabel 1.3 menunjukkan bahwa dari jumlah 25 siswa maka terdapat 11 siswa yang bisa menyebutkan 5 kosakata benda dengan persentase $44,00 \%$; terdapat 10 siswa yang bisa menyebutkan 4 kosakata benda dengan persentasi $40 \%$; terdapat 3 siswa yang bisa menyebutkan 3 kosakata benda dengan persentasi $12 \%$; dan terdapat 1 siswa yang hanya menyebutkan 2 kosakata benda dengan persentasi $4 \%$.
Tabel 1.4 Pemilihan Kata Sifat

\begin{tabular}{|c|c|c|}
\hline $\begin{array}{c}\text { Jumlah Kata } \\
\text { Sifat }\end{array}$ & Frekuensi & Persentase \\
\hline 5 & 8 & 32,00 \\
\hline 4 & 11 & 44,00 \\
\hline 3 & 4 & 16,00 \\
\hline 2 & 2 & 8,00 \\
\hline 1 & 0 & 0,00 \\
\hline Jumlah & 25 & 100 \\
\hline
\end{tabular}

Data pada tabel 1.4 menunjukkan bahwa dari jumlah 25 siswa maka terdapat 8 siswa yang bisa menyebutkan 5 kosakata sifat dengan persentase $32 \%$; terdapat 11 siswa yang bisa menyebutkan 4 kosakata sifat dengan persentasi $44 \%$; terdapat 4 siswa yang bisa menyebutkan 3 kosakata sifat dengan persentasi $16 \%$; dan terdapat 2 siswa yang hanya menyebutkan 2 kosakata sifat dengan persentasi $8 \%$.

Berikut ini hasil skor perolehan kosakata kerja, benda, dan sifat siswa kelas VI Sekolah Madrasah Ibtidaiyah Pangeran Hidayatullah.

Tabel 1.5 Skor Perolehan Kosakata Kerja, Benda, dan Sifat

\begin{tabular}{|c|c|c|c|c|c|c|}
\hline No. & Nama Siswa & $\begin{array}{c}\text { Kosakata } \\
\text { Kerja }\end{array}$ & $\begin{array}{c}\text { Kosakata } \\
\text { Benda }\end{array}$ & $\begin{array}{c}\text { Kosakata } \\
\text { Sifat }\end{array}$ & Jumlah & Nilai \\
\hline 1 & A. Kholifa Husain & 5 & 5 & 4 & 14 & 28 \\
\hline 2 & Ahmad Khulaify & 5 & 4 & 5 & 14 & 28 \\
\hline 3 & A. Mursyidi & 4 & 5 & 4 & 13 & 26 \\
\hline 4 & B. Ridha & 3 & 4 & 5 & 12 & 24 \\
\hline 5 & Fadhila & 4 & 5 & 4 & 13 & 26 \\
\hline 6 & Nayla Rahma Izzati & 5 & 5 & 3 & 13 & 26 \\
\hline 7 & Nayna Salsabilla D.S & 5 & 4 & 4 & 13 & 26 \\
\hline 8 & Nur Ahro Zihah & 4 & 3 & 3 & 10 & 20 \\
\hline 9 & Nur Askiya & 5 & 4 & 3 & 12 & 24 \\
\hline 10 & Nur Kholishoh & 3 & 5 & 4 & 12 & 24 \\
\hline 11 & Nur Syifa & 5 & 4 & 2 & 11 & 22 \\
\hline 12 & Nurul Azkia & 4 & 5 & 2 & 11 & 22 \\
\hline 13 & Magfiroh Husna Rifa'i & 3 & 4 & 5 & 12 & 24 \\
\hline
\end{tabular}




\begin{tabular}{|c|c|c|c|c|c|c|}
\hline 14 & Mariatul Khibtiah & 3 & 4 & 4 & 11 & 22 \\
\hline 15 & M. Ahsan Rama Dhoni & 4 & 4 & 5 & 13 & 26 \\
\hline 16 & M. Fauzi & 4 & 5 & 4 & 13 & 26 \\
\hline 17 & M. Ismail & 2 & 5 & 4 & 11 & 22 \\
\hline 18 & M. Naufal & 3 & 5 & 4 & 12 & 24 \\
\hline 19 & M. Rifki & 5 & 2 & 3 & 10 & 20 \\
\hline 20 & M. Subhan & 3 & 4 & 5 & 12 & 24 \\
\hline 21 & Mustofa & 4 & 5 & 5 & 14 & 28 \\
\hline 22 & Robiatul Adawiah & 2 & 5 & 4 & 11 & 22 \\
\hline 23 & Siti Munawarah & 5 & 3 & 4 & 12 & 24 \\
\hline 24 & Siti Nawilah & 5 & 4 & 5 & 14 & 28 \\
\hline 25 & Soraya Zaida & 4 & 3 & 5 & 12 & 24 \\
\hline \multicolumn{5}{|c|}{ Jumlah } & 305 & 610 \\
\hline
\end{tabular}

Berikut ini hasil perhitungan statistik mengenai penguasaan kosakata bahasa Indonesia siswa kelas VI Sekolah Madrasah Ibtidaiyah Pangeran Hidayatullah dengan menggunakan analisis statistik deskriptif sebagai berikut:

Mean:

$$
\bar{x}=\frac{1}{n} \sum_{i=1}^{n} x_{i}
$$

Standar Deviasi:

$$
s=\sqrt{\frac{n \sum_{i=1}^{n} x_{i}^{2}-\left(\sum_{i=1}^{n} x_{1}\right)^{2}}{n(n-1)}}
$$

\section{Keterangan :}

$\mathrm{s} 2=$ varian

$\mathrm{s}=$ standar deviasi (simpangan baku)

$\mathrm{xi}=$ nilai $\mathrm{x}$ ke-i

$\mathrm{n}=$ ukuran sampel

$\bar{x}=$ mean (rata-rata)

Tabel 1.6 Deskripsi Penguasaan Kosakata Bahasa Indonesia

\begin{tabular}{|c|c|c|c|c|c|c|}
\hline & $\mathrm{N}$ & Minimum & Maksimum & Sum & Mean & $\begin{array}{c}\text { Std. } \\
\text { Deviation }\end{array}$ \\
\hline $\begin{array}{c}\text { PENGUASAAN } \\
\text { KOSAKATA }\end{array}$ & 25 & 20,00 & 28,00 & 608 & 24,40 & 2,36 \\
Valid N & 25 & & & & \\
\hline
\end{tabular}

Berdasarkan tabel 1.6 diketahui nilai mean empiris atau nilai rata-rata sebesar 24,40; nilai minimum atau nilai terendah yang diperoleh siswa sebesar 20,00; nilai maksimum atau nilai tertinggi yang

diperoleh siswa sebesar 28,00; standar deviasi atau simpangan baku sebesar 2,36; dan sum atau nilai perolehan dari seluruh 
siswa adalah 608. Kemudian ditentukan kategorisasi agar lebih jelas lagi dengan langkah awalnya menentukan interval kategori. Interval kategori dilakukan dengan rumus sebagai berikut.

Interval $=\underline{\text { skor tertinggi-skor terendah }}$

Jumlah kategori

$$
\begin{aligned}
& =\frac{28-20}{5} \\
& =1,6=2
\end{aligned}
$$

Setelah mendapatkan interval untuk kategorisasi, kemudian digambarkan tabel kategorisasi penguasaan kosakata bahasa Indonesia siswa kelas VI Sekolah Madrasah Ibtidaiyah Pangeran Hidayatullah yang dapat dilihat pada tabel berikut.

Tabel 1.7

Kategori Penguasaan Kosakata Bahasa Indonesia

\begin{tabular}{|c|c|}
\hline Interval & Kategori \\
\hline $20-21$ & Sangat Rendah \\
\hline $22-23$ & Rendah \\
\hline $23-24$ & Sedang \\
\hline $25-26$ & Tinggi \\
\hline $27-28$ & Sangat Tinggi \\
\hline
\end{tabular}

Berikutnya hasil penelitian ini akan disesuaikan dengan kategorisasi yang sudah ditentukan yang dapat dilihat pada tabel di bawah ini.

Tabel 1.8

Deskripsi Penguasaan Kosakata Bahasa Indonesia

\begin{tabular}{|c|c|c|c|}
\hline Interval & Frekuensi & Persentase & Kategori \\
\hline $20-21$ & 2 & 8,00 & $\begin{array}{c}\text { Sangat } \\
\text { Rendah }\end{array}$ \\
\hline $22-23$ & 5 & 20,00 & Rendah \\
\hline $23-24$ & 8 & 32,00 & Sedang \\
\hline $25-26$ & 6 & 24,00 & Tinggi \\
\hline $27-28$ & 4 & 16,00 & $\begin{array}{c}\text { Sangat } \\
\text { Tinggi }\end{array}$ \\
\hline
\end{tabular}

Dari tabel 1.8 dapat diketahui bahwa terdapat 2 siswa $(8,00 \%)$ penguasaan kosakata yang sangat rendah; 5 siswa $(20,00$ $\%)$ penguasaan kosakatanya rendah; 8 siswa $(32,00 \%)$ penguasaan kosakatanya sedang; 6 siswa $(24,00 \%)$ penguasaan kosakatanya tinggi; dan 4 siswa $(16,00 \%)$ penguasaan kosakatanya sangat tinggi. Berdasarkan data pada tabel 1.8 dapat dijelaskan bahwa penguasaan kosakata bahasa Indonesia berada dalam kategori sedang. Hal ini dapat dilihat dari persentase sebesar 32,00 \% dengan frekuensi 8 siswa. Kemudian, jika melihat nilai rata-rata sebesar 24,40 maka kita menemukan dalam tabel kategorisasi bahwa nilai 24,40 berada pada interval $23-$ 24 sehingga dapat dinyatakan bahwa penguasaan kosakata bahasa Indonesia siswa berada pada kategori sedang.

\section{Kemampuan Berbicara Siswa Kelas VI Sekolah Madrasah Ibtidaiyah Pangeran Hidayatullah}

Berdasarkan penelitian yang dilakukan pada siswa kelas VI Sekolah Madrasah Ibtidaiyah Pangeran Hidayatullah, maka diperoleh data sebagai berikut:

Tabel 1.9

Hasil Penelitian mengenai Kemampuan Berbicara Siswa

\begin{tabular}{|c|c|c|}
\hline No. & Nama Siswa & Nilai \\
\hline 1 & A. Kholifa Husain & 11 \\
\hline 2 & Ahmad Khulaify & 10 \\
\hline 3 & A. Mursyidi & 9 \\
\hline 4 & A. Ridha & 12 \\
\hline 5 & Fadhila & 9 \\
\hline 6 & Nayla Rahma Izzati & 10 \\
\hline 7 & Nayna Salsabilla D.S & 11 \\
\hline 8 & Nur Ahro Zihah & 11 \\
\hline 9 & Nur Askiya & 11 \\
\hline 10 & Nur Kholishoh & 10 \\
\hline 11 & Nur Syifa & 10 \\
\hline 12 & Nurul Azkia & 11 \\
\hline 13 & Magfiroh Husna Rifa'i & 11 \\
\hline 14 & Mariatul Khibtiah & 11 \\
\hline 15 & M. Ahsan Rama Dhoni & 11 \\
\hline 16 & M. Fauzi & 6 \\
\hline 17 & M. Ismail Naufal & 12 \\
\hline 18 & & 8 \\
\hline
\end{tabular}




\begin{tabular}{|c|c|c|}
\hline 19 & M. Rifki & 11 \\
\hline 20 & M. Subhan & 9 \\
\hline 21 & Mustofa & 12 \\
\hline 22 & Robiatul Adawiah & 8 \\
\hline 23 & Siti Munawarah & 10 \\
\hline 24 & Siti Nawilah & 12 \\
\hline 25 & Soraya Zaida & 6 \\
\hline \multicolumn{2}{|r|}{ JUMLAH } & 252 \\
\hline
\end{tabular}

Untuk mengetahui penguasaan kosakata bahasa Indonesia siswa kelas VI Sekolah Madrasah Ibtidaiyah Pangeran Hidayatullah, maka data tabel 1.9 akan dideskripsikan per indikator sesuai dengan lembar observasi dan dari hasil perhitungan statistik sehingga diperoleh sebagai berikut:

Tabel 1.10

\section{Pengucapan}

\begin{tabular}{|c|c|c|c|c|}
\hline No. & Kategori & Nilai & Frekuensi & Persentase \\
\hline 1 & Baik & 2 & 19 & 76,00 \\
\hline 2 & Cukup & 1 & 6 & 24,00 \\
\hline \multicolumn{3}{|c|}{ Jumlah } & 25 & 100,00 \\
\hline
\end{tabular}

Data pada tabel 1.10 menunjukkan bahwa dari 25 siswa, terdapat 19 siswa yang pengucapannya baik dengan persentase $76,00 \%$ dan terdapat 6 siswa yang pengucapannya cukup dengan persentase $24,00 \%$.

Tabel 1.11

Artikulasi

\begin{tabular}{|c|c|c|c|c|}
\hline No. & Kategori & Nilai & Frekuensi & Persentase \\
\hline 1 & Baik & 2 & 17 & 68,00 \\
\hline 2 & Cukup & 1 & 8 & 32,00 \\
\hline \multicolumn{3}{|c|}{ Jumlah } & 25 & 100,00 \\
\hline
\end{tabular}

Data pada tabel 1.11 menunjukkan bahwa dari 25 siswa, terdapat 17 siswa yang penggunaan artikulasinya baik dengan persentase $68,00 \%$ dan terdapat 8 siswa yang berada pada kategori cukup dengan persentase $32,00 \%$.

Tabel 1.12

Intonasi

\begin{tabular}{|c|c|c|c|c|}
\hline No. & Kategori & Nilai & Frekuensi & Persentase \\
\hline 1 & Baik & 2 & 20 & 80,00 \\
\hline
\end{tabular}

\begin{tabular}{|c|c|c|c|c|}
\hline 2 & Cukup & 1 & 8 & 20,00 \\
\hline \multicolumn{3}{|c|}{ Jumlah } & 25 & 100,00 \\
\hline
\end{tabular}

Data pada tabel 1.12 menunjukkan bahwa dari 25 siswa, terdapat 20 siswa yang penggunaan intonasinya baik dengan persentase $80,00 \%$ dan terdapat 8 siswa yang penggunaan intonasinya cukup dengan persentase $20,00 \%$.

Tabel 1.13

Pemilihan Kata

\begin{tabular}{|c|c|c|c|c|}
\hline No. & Kategori & Nilai & Frekuensi & Persentase \\
\hline 1 & Baik & 2 & 15 & 60,00 \\
\hline 2 & Cukup & 1 & 10 & 40,00 \\
\hline \multicolumn{3}{|c|}{ Jumlah } & 25 & 100,00 \\
\hline
\end{tabular}

Data pada tabel 1.13 menunjukkan bahwa dari 25 siswa, terdapat 15 siswa yang pemilihan katanya baik dengan persentase $60,00 \%$ dan terdapat 10 siswa yang berada pada kategori cukup dengan persentase $40,00 \%$.

Tabel 1.14

Mimik

\begin{tabular}{|c|c|c|c|c|}
\hline No. & Kategori & Nilai & Frekuensi & Persentase \\
\hline 1 & Baik & 2 & 17 & 68,00 \\
\hline 2 & Cukup & 1 & 8 & 32,00 \\
\hline \multicolumn{3}{|c|}{ Jumlah } & 25 & 100,00 \\
\hline
\end{tabular}

Data pada tabel 1.14 menunjukkan bahwa dari 25 siswa, terdapat 17 siswa yang mimiknya baik dengan persentase $68,00 \%$ dan terdapat 8 siswa yang berada pada kategori cukup dengan persentase $32,00 \%$.

Tabel 1.15

Pemakaian Bahasa yang Baku

\begin{tabular}{|c|c|c|c|c|}
\hline No. & Kategori & Nilai & Frekuensi & Persentase \\
\hline 1 & Baik & 2 & 14 & 56,00 \\
\hline 2 & Cukup & 1 & 11 & 44,00 \\
\hline \multicolumn{3}{|c|}{ Jumlah } & 25 & 100,00 \\
\hline
\end{tabular}

Data pada tabel 1.15 menunjukkan bahwa dari 25 siswa, terdapat 14 siswa yang pemakaian bahasanya baik dengan persentase $56,00 \%$ dan terdapat 11 siswa yang berada pada kategori cukup dengan persentase $44,00 \%$.

Selanjutnya, untuk mengetahui tingkat penguasaan kemampuan berbicara maka 
akan dilakukan berdasarkan perhitungan statistik. Berikut hasil perhitungan statistiknya.

Mean:

$$
\bar{x}=\frac{1}{n} \sum_{i=1}^{n} x_{i}
$$

$$
s=\sqrt{\frac{n \sum_{i=1}^{n} x_{i}^{2}-\left(\sum_{i=1}^{n} x_{1}\right)^{2}}{n(n-1)}}
$$

\section{Keterangan :}

$$
\begin{aligned}
& \mathrm{s} 2=\text { varian } \\
& \mathrm{s}=\text { standar deviasi (simpangan baku) } \\
& \mathrm{xi}=\text { nilai } \mathrm{x} \text { ke- } \mathrm{i} \\
& \mathrm{n}=\text { ukuran sampel } \\
& \bar{x}=\text { mean (rata-rata) }
\end{aligned}
$$

\section{Standar Deviasi:}

Tabel 1.16

Deskripsi Kemampuan Berbicara Bahasa Indonesia

\begin{tabular}{|c|c|c|c|c|c|c|}
\hline & $\mathrm{N}$ & Minimum & Maksimum & Sum & Mean & $\begin{array}{c}\text { Std. } \\
\text { Deviation }\end{array}$ \\
\hline $\begin{array}{c}\text { PENGUASAAN } \\
\text { KOSAKATA }\end{array}$ & 25 & 6,00 & 12,00 & 252 & 10,08 & 1,68 \\
Valid N & 25 & & & & & \\
\hline
\end{tabular}

Berdasarkan tabel 1.16 dapat diketahui bahwa nilai mean empiris sebesar 10,08; nilai minimum atau nilai terendah yang diperoleh siswa sebesar 6,00; nilai maksimum atau nilai tertinggi yang diperoleh siswa sebesar 12,00; standar deviasi atau simpangan baku sebesar 1,68; dan sum atau nilai perolehan dari seluruh siswa adalah 252. Kemudian ditentukan kategorisasi agar lebih jelas lagi dengan langkah awalnya menentukan interval kategori. Interval kategori dilakukan dengan rumus sebagai berikut.

Interval $=\underline{\text { skor tertinggi-skor terendah }}$ Jumlah kategori

$$
\begin{aligned}
& =\frac{12-6}{5} \\
& =1,2=1
\end{aligned}
$$

Setelah mendapatkan interval untuk kategorisasi, kemudian digambarkan tabel kategorisasi penguasaan kemampuan berbicara siswa kelas VI Sekolah Madrasah Ibtidaiyah Pangeran Hidayatullah yang dapat dilihat pada tabel berikut.
Tabel 1.17

Kategorisasi Kemampuan BerbicaraBahasa Indonesia

\begin{tabular}{|c|c|}
\hline Interval & Kategori \\
\hline $6-7$ & Sangat Rendah \\
\hline $8-9$ & Rendah \\
\hline $10-11$ & Sedang \\
\hline $12-13$ & Tinggi \\
\hline $14-15$ & Sangat Tinggi \\
\hline
\end{tabular}

Berikutnya hasil penelitian ini akan disesuaikan dengan kategorisasi yang sudah ditentukan yang dapat dilihat pada tabel di bawah ini.

Tabel 1.18

Deskripsi Kemampuan Berbicara Bahasa Indonesia

\begin{tabular}{|c|c|c|c|}
\hline Interval & Frekuensi & Persentase & Kategori \\
\hline $6-7$ & 2 & 8,00 & $\begin{array}{c}\text { Sangat } \\
\text { Rendah }\end{array}$ \\
\hline $8-9$ & 5 & 20,00 & Rendah \\
\hline $10-11$ & 14 & 56,00 & Sedang \\
\hline $12-13$ & 4 & 16,00 & Tinggi \\
\hline $14-15$ & 0 & 0,00 & $\begin{array}{c}\text { Sangat } \\
\text { Tinggi }\end{array}$ \\
\hline
\end{tabular}

Dari tabel 1.18 dapat dilihat bahwa terdapat 2 siswa $(8,00 \%)$ yang kemampuan 
berbicara sangat rendah; 5 siswa $(20,00 \%)$ kemampuan berbicara rendah; 14 siswa $(56,00 \%)$ kemampuan berbicara sedang; dan 4 siswa kemampuan berbicara tinggi.

Berdasarkan data tersebut dapat dinyatakan bahwa kemampuan berbicara siswa berada dalam kategori sedang. Hal ini dapat dilihat dari persentase sebesar 56,00\% dengan frekuensi 14 siswa. Kemudian, jika melihat nilai rata-rata sebesar 10,08 maka kita menemukan dalam tabel kategorisasi bahwa nilai 10,08 berada pada interval $10-$ 11 sehingga dapat dinyatakan bahwa kemampuan berbicara siswa berada pada kategori sedang.

Dengan demikian, dari hasil analisis data dapat dinyatakan bahwa penguasaan kosakata bahasa Indonesia dan kemampuan berbicara bahasa Indonesia siswa kelas VI Sekolah Madrasah Ibtidaiyah Pangeran Hidayatullah berada pada kategori sedang.

\section{PENUTUP}

Berdasarkan hasil analisis dapat disimpulkan bahwa penguasaan kosakata bahasa Indonesia dan kemampuan berbicara bahasa Indonesia siswa kelas VI Sekolah Madrasah Ibtidaiyah Pangeran Hidayatullah berada pada kategori sedang.

Penguasaan kosakata bahasa Indonesia berada pada kategori sedang. Hal ini terlihat dari persentase terbanyak, yakni sebesar $32,00 \%$ dengan frekuensi 8 siswa. Kemudian, jika melihat nilai rata-rata sebesar 24,40 maka kita menemukan dalam tabel kategorisasi bahwa nilai 24,40 berada pada interval 23-24 sehingga dapat dinyatakan bahwa penguasaan kosakata bahasa Indonesia siswa berada pada kategori sedang.

Kemampuan berbicara bahasa Indonesia siswa kelas VI Sekolah Madrasah Ibtidaiyah Pangeran Hidayatullah berada kategori sedang. Hal ini terlihat dari

ntase terbanyak, yakni sebesar sebesar $56,00 \%$ dengan frekuensi 14 siswa. Kemudian, jika melihat nilai rata-rata sebesar 10,08 maka kita menemukan dalam tabel kategorisasi bahwa nilai 10,08 berada pada interval $10-11$ sehingga dapat dinyatakan bahwa kemampuan berbicara siswa berada pada kategori sedang.

\section{DAFTAR PUSTAKA}

Arifin, Zainal. 2014. Evaluasi Pembelajaran. Bandung: Remaja Rosdakarya.

Ayuandia, dkk. 2017. "Meningkatkan Keterampilan Berbicara melalui Metode Karyawisata pada Anak Kelompok B Lab School PAUD UNIB Kota Bengkulu." JurnalPotensia, Vol. 2, No. 1, hlm. 32-38.

Azwar, Saifuddin. 2013. Penyusunan Skala Psikologi. Yogyakarta: Pustaka Pelajar.

Budiyono, Herman. 2014. "Proses Pembelajaran Kemampuan Menulis dan Dasar Argumen Keyakinan Guru di Sekolah Menengah Pertama Nusa." JurnalMlangun, Vol. 8, No. 2, hlm. 173-184.

Hestiyana. 2017. “Tindak Imperatif dalam Wacana Kelas: Kajian Strategi Bertutur di SDN Ngumbul 3 Kecamatan Tulakan." Jurnal Batra, Vol. 3, No. 2, hlm. 157-166.

Hornby, A. S. 2010. Ocford Advence Learners Dictionary of Current English. AS: Oxford University Press.

Mabruri, Z dan Ferry. 2017. "Peningkatan Keterampilan Berbicara Pembelajaran Bahasa Indonesia Kelas IV melalui Penerapan Strategi Role Playing SD Negeri Ploso 1 Pacitan." Naturalistic, Vol. 1, No. 2, hlm. 112-117.

Mulyati, Yeti. 2017. "Kosakata Siswa Sekolah Dasar Kelas Rendah (Kajian Jenis Kata, Bentuk Kata, Jenis Makna, dan Medan Makna." Jurnal Bahasa dan Seni, Vol. 45, No. 1, hlm. 99107.

Nawawi, H., \& Martini, M. 2012. Penelitian Terapan. Yogyakarta: Gadjah Mada University Press. 
Nurhadi, Roekman. 1995. Dimensi-Dimensi Belajar Bahasa Kedua. Bandung: Sinar Baru.

Pramesti, Utami D. 2015. "Peningkatan Penguasaan Kosakata Bahasa Indonesia dalam Keterampilan Membaca Melalui Teka-Teki Silang (Penelitian Tindakan di Kelas VI SDN Surakarta 2 Kecamatan Suranenggala, Kabupaten Cirebon, Jawa Barat)." JurnalPuitika, Vol. 11, No. 1, hlm. 82-93.

Purwanto, Edy. 2016. Metodologi Penelitian Kuantitatif. Yogyakarta: Pustaka Pelajar.

Riduwan. 2019. Dasar-Dasar Statistik. Bandung: Alfabet.

Roberts, T. A. 2014. "Not so silent after all examination and analysis of the silent stage in childhood second language acquisition." Journal Early Childhood Research Quarterly (29), pp 24-40.

Rusda. 2017. Pengaruh Penguasaan Kosakata terhadap Kemampuan Berbicara Bahasa Indonesia Peserta Didik di SDN 2 Pulau Sarappo Lompo Kecamatan Liukang Tupabbiring Kabupaten Pangkep. Skripsi. Makassar: Fakultas Tarbiyah dan Keguruan UIN Alauddin Makassar.

Sakila. 2017. "Meningkatkan Kemampuan Siswa Menulis Puisi dengan Menggunakan Media Gambar." JurnalTotobuang, Vol. 5, No. 2, hlm. 199-213.

Schmidt, J. C. 2010. Longman Dictionary of Language Teaching and Applied Linguistic Third Edition. Belmant: Cengage Learning.
Soenardi, Djiwandono. 2009. Tes Bahasa: Pegangan bagi Pengajar Bahasa. Jakarta: Indeks.

Solchan, dkk. 2009. Pendidikan Bahasa Indonesia di SD. Jakarta: Universitas Terbuka.

Subana \& Sunarti. 2012. Strategi Belajar Mengajar Bahasa Indonesia. Bandung: Alfabeta.

Subyantoro. 2012. "Penguasaan Kosakata Budaya Lokal pada Siswa SD di Lingkungan Kawasan Industri Kota Semarang." Dalam Prosiding Pengembangan Kebahasaan dan Kesusastraan melalui Nilai-Nilai Kearifan Lokal untuk Penguatan Jati Diri Bangsa, PIBSI XXXIV, hlm. $710-721$.

Sugiyono. 2016. Metode Penelitian Kombinasi (Mixed Methods). Bandung: Alfabeta.

Sugiyono. 2016. Metode Penelitian Kuantitatif, Kualitatif, dan $R \& D$. Bandung: Alfabeta.

Tarigan, Henry G. 2012. Penguasaan Kosakata dalam Kinerja Bahasa. Bandung: Remaja Rosdakarya. Suatu Keterampilan Berbahasa. Bandung: Angkasa.

2015. Pengajaran Kosakata. Bandung: Angkasa.

Wendra, I Wayan. 2009. Buku Ajar Keterampilan Berbicara. Singaraja: Universitas Pendidikan Ganesha.

Widyastuti, Ana. 2016. "Pengaruh Minat Membaca dan Penguasaan Kosakata terhadap Keterampilan Berbicara Pidato." JurnalDeiksis, Vol. 8, No. 1, hlm. 27-38. 